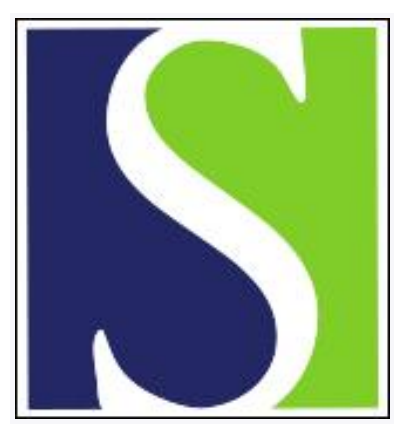

Scand J Work Environ Health 1975;1(1):45-49

https://doi.org/10.5271/sjweh.2861

Issue date: Mar 1975

Changes in the nasal mucosa after exposure to copper salt dust. A preliminary report.

by Askergren A, Mellgren M

Key terms: copper salt dust; exposure; industrial exposure; metal work; nasal mucosa; salt dust

This article in PubMed: www.ncbi.nlm.nih.gov/pubmed/1235857

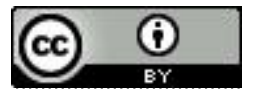




\title{
Changes in the nasal mucosa after exposure to copper salt dust A preliminary report
}

\author{
by ALF ASKERGREN, M.D., and MONICA MELLGREN, M.D. ${ }^{1}$
}

\begin{abstract}
ASKMRGREN, A. and MELLGREN, M. Changes in the nasal mucosa after exposure to copper salt dust: A preliminary report. Scand. $j$. work environ. \& health 1 (1975) 45-49. Ten metal workers with varying exposure to complex copper salts in dust form, six other metal workers not exposed, and nine construction workers in other occupational categories, also unexposed to the salts, were compared with in other to history and mucosal changes in the nose. There were subjective symptoms of metal dust exposure in the group exposed to the copper salts. Suspected early of metal dust expos the mucous membranes were noted in subjects exposed for long atrophic changes in the mucous membranes were noted breathing masks should be periods of time. Protective equipmentening or a surface finish on the copper sheeting is capable of preventing the release of dust.

Key worcis: industrial exposure, copper salt dust, metal work, nasal mucosa.
\end{abstract}

Copper sheeting, treated so as to provide it with a patinated appearance right from the beginning, has been used as a roofing material for a number of years. When this sheeting is worked with tools, some of the patina is released in the form of dust. The following investigation was performed after complaints had been received from metal workers about a metallic taste and irritated nasal and oral mucosa.

\section{SUBJECTS AND METHODS}

Eleven sheet-metal workers who had worked with factory patinated copper sheeting were examined together with two other groups, one containing six sheet-metal workers who had never carried out such work and one comprising

1. The Foundation for Industrial Safety and Health in the Construction Industry, Stockholm, Sweden.

Reprint requests to: Dr. Alf Askergren, The Foundation for Industrial Safety and Health in the Construction Industry, Mariehällsvägen 44, 16171 Bromma, Sweden. nine construction workers of various categories except sheet-metal workers. The subjects in these groups were chosen so as to correspond in age to the sheet-metal workers exposed to the patinated copper. The same physician examined all subjects. The mucous membranes of the throat and nose were examined first, and their state was noted. The occupational history and history in other respects were then taken. Thus the physician was unaware of the category to which the patient belonged at the time of the inspection of the throat and nose.

At our request, the sheeting manufacturer performed an assay of the dust released.

\section{RESULTS}

The constituents of the patina dust, according to the manufacturer's analysis, can be found in table 1 .

The examined patients and the results of the study are shown in table 2. Six subjects displayed mucous membranes which provided a «thin» impression, i.e., 
increase in vascularity and/or superficial epistatic vessels, and which also gave the impression of increased adhesion to the underlying tissue. All of these subjects were sheet-metal workers. Five were 60 years of age or more and had been exposed to the dust in question. However, one had had surgery for a septum deviation. He was therefore excluded from the material and not included in the table. The sixth subject was less than 35 years of age and was unexposed. Strilkingly dry mucosa without any other visible changes was found in four subjects, one of whom was a member of the exposed group and older than 50 years and one of whom was an unexposed sheet-metal worker also more than 50 years of age. The remaining two belonged to other professions and were less than 50 years of age. Both changes, i.e., "thin» and dry mucosa, were found mainly on the septum, whereas livid mucosa, also reported in table 2, was found on the conchae.

As shown in table 2 the material comprised ten subjects who were 60 or more. Thus four of the five subjects with "thin" mucous membranes were found in this group. These four subjects were also simultaneously the ones who had been exposed to the patinated copper for the longest periods of time. No difference was found in the distribution of "normal» or livid nasal mucosa, or of those with mucoid secretion, among the various age groups or between the exposed and un exposed groups.

Nine of the ten exposed subjects complained about a sweet taste in conjunction with exposure, seven complained of a runny nose, and six of a feeling of mucosal irritation in the mouth or eyes. Eight reported that their distress began almost immediately after initiated exposure, whereas the other two experienced no discomfort until after 1 to 2 hours. However, ventilation was reported to have had great importance. Half of the exposed subjects were free from their complaints 2 to 3 hours after concluded exposure, while distress disappeared in the remaining subjects after an hour or so. Two complained of residual discomfort, one of irritation of the conjuctiva with lacrimation and the other of lesions in his nose on a few occasions.
Table 1. Percentage of the constituents of the patina dust.

Constituent

$0 / 0$

Copper hydroxide nitrate, $\mathrm{Cu}\left(\mathrm{NO}_{3}\right)_{2} \cdot 3 \mathrm{Cu}(\mathrm{OH})_{2}$

Copper hydroxide sulfate,

$$
\mathrm{CuSO}+3 \mathrm{Cu}(\mathrm{OH})_{2}
$$

Copper hydroxide chloride,

$\mathrm{CuCl}_{2} \cdot 3 \mathrm{Cu}(\mathrm{OH})_{2}$

Copper hydroxide carbonate,

$\mathrm{CuCO}_{3} \cdot \mathrm{Cu}(\mathrm{OI})_{2}$

Copper silicate, CuSiO3

Cupric oxide, CuO

Ferric oxide, $\mathrm{Fe}_{2} \mathrm{O}$

Water, $\mathrm{H}_{2} \mathrm{O}$

\section{DISCUSSION}

Four compounds dominated the patina dust in our study: copper hydroxide nitrate, copper hydroxide sulfate, copper silicate, and cupric oxide. The sulfate compound is best known from the toxicological point of view. However, the mutual roles played by the different comm pounds in the etiology of the cited symptoms can obviously not be assessed. According to the literature, all four com pounds are known to act as local irritants.

Copper sulfate is the main copper compound mentioned in the toxicological literature. The symptoms produced by inhalation of dust or steam containing such compounds have been summarized by Stokinger (16): metal-fume lever, sneezing, cough, swollen mucosa, and irritation of the nose and pharynx. Luchsinger (9) described a case of superfical ulceration of the nasal septum following the inhalation of atomized copper dust and one case of deposits on the nasal mucosa and slightly hemorrhagic, swollen conchae following inhalation of fumes from a copper solution bath. Pimentel and Marques (14) described interstitial pulmonary changes after the ixhalation of a copper sulfate solution neutralized with hydrated lime, a mixture used to spray grapes. They were able to reproduce these changes in guinea pigs and called the condition "vineyard sprayer's lung." Changes in the mucous membranes of the eyes during exposure to copper salts have also been described (18). The effects of the oral ingestion of copper compounds are 
reported by Stokinger (16) to be metallic taste and gastrointestinal distress in the form of nausea, colic, vomiting, and diax. rhea. Allergic reactions to copper appear to be relatively uncommon, but skin and mucosal changes have been described $(1,3,13$, 17). An anticaries effect produced by treatment with copper has been described by Giampiccolo et al. (4).

The local effect of nitrate has been described by Sax (15) as unknown, whereas oral administration in small doses has been said to produce malaise, headache, and some psychic effect (11, 15).

No possible toxic properties for copm per silicate appear to have been reported. Compounds such as sodium silicate have been described in the standard toxicologm ical literature as having a slightly irritaling local efm fect $(5,11,15)$.

All exposed sub. jects reported one or more of the possible symptoms, with the exception of metal-fume fever, which may develop following exposure to the compounds. Six of the subjects reporting

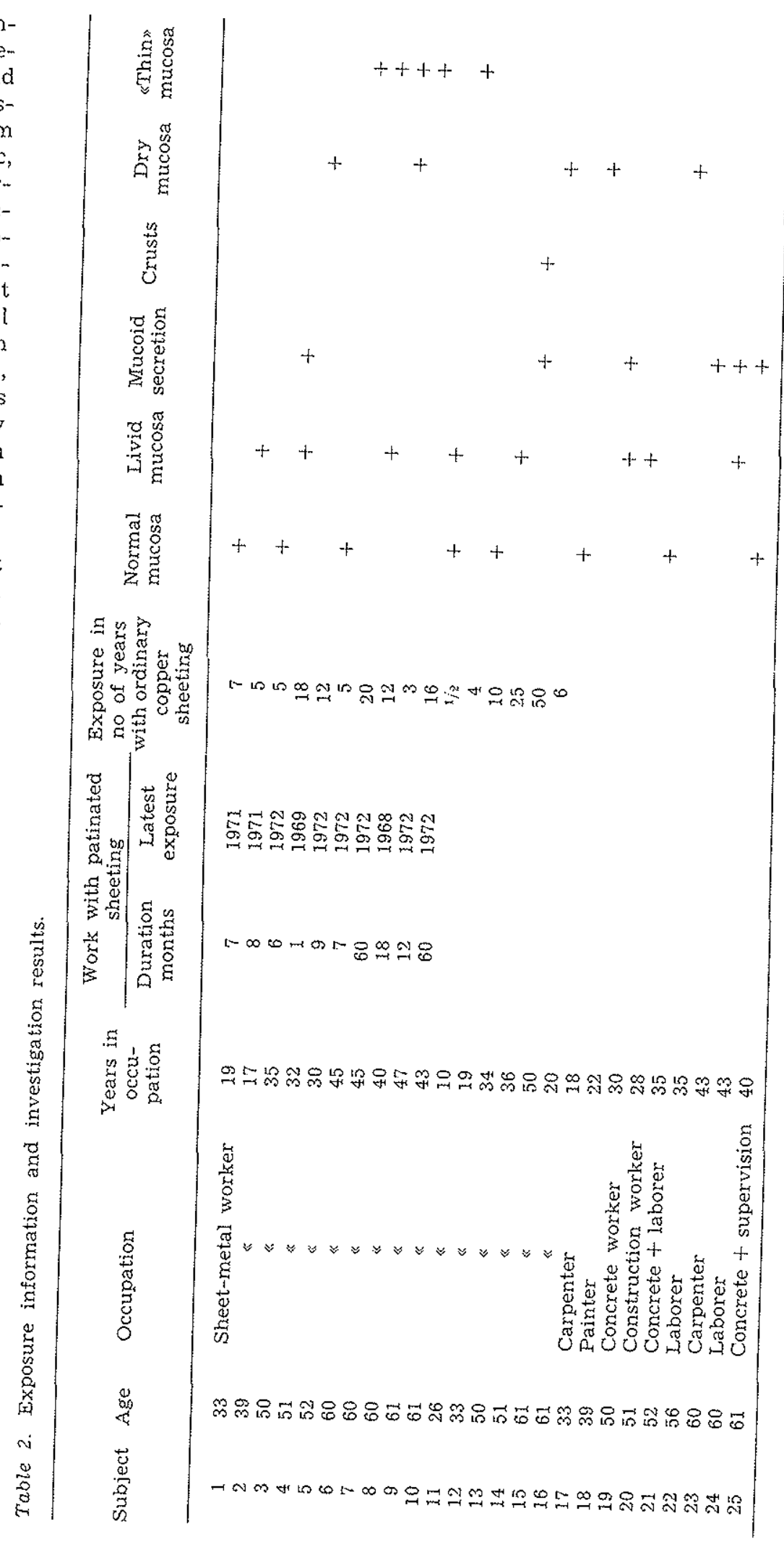


distress during exposure to copper dust claimed that they experienced these symptoms even in work with old, naturally oxidized copper sheeting but that the symptoms were never intense. This work usually involves repairs which are perw formed sporadically and never last long.

Mucosal changes of the type we found probably belong to categories such as "rhinitis sicca anterior» and "atrophic rhinitis/ozena.» The boundaries between these conditions are not firmly defined, and the conditions are often regarded as different stages of the same disorder (10). The etiology is still obscure. Available information suggests a prevalence of the mucosal changes in about $3 \%$ of different populations $(7,10,12)$. Jakobi (7) summarized, e.g., the histological changes which can be observed in mucosal atrophy, metaplasia of ciliated epithelium, degeneration of follicular cells, vascular changes, and mucosal fibrosis. He noted that true ozena is becoming increasingly rare. In his monograph Holopainen (6) confirmed previous statements to the effect that the boundary between squamous epithelium and mucosa varies from individual to individual. He thinks it likely that protracted infection is the most common cause of atrophic rhinitis.

Four of the ten exposed sheet-metal workers displayed atrophic mucosal changes. These four subjects were also the ones with the longest exposure time. It is notable that one of the examined subjects had not been exposed to the substances for at least 6 months prior to the examination (performed in May 1973). One patient even reported a previous exposure occasion 5 years earlier.

The fact that one man with «thin» mucosa was found among the 15 unexposed subjects should hardly have any effect on the picture as a whole. The association between inhalation of copper and swollen conchae, described by Luchsinger (9), was not found in this study. The number of cases with livid mucosa (mainly on the conchae) and the distribution of these cases among the three occupational groups and age groups did not permit the drawing of any conclusions; neither could conclusions be drawn concerning the finding of dry mucosa.
In a material comprising 330 cases of cancer of the nose and sinus, Larsson and Mårtensson (8) had two patients with a history of protracted atrophic rhinitis. Baumslag et al. (2) discovered high values for certain known carcinogens during a study of trace metals in snuff and a possible link to cancer of the maxillary sinus. Copper was also found in relatively large amounts. However, we were unable to find any information in the literature pointing to carcinogenity for copper.

There was no opportunity for histological confirmation of the diagnosis, nor could any measurements be made at this stage of dust exposure. No one reported using a breathing mask in work with either old, oxidized copper sheeting or with factory-patinated sheeting. Howm ever, both patient histories and signs of mucosal changes suggest that exposure was extensive. Protective equipment in the form of breathing filters should therefore be used in this type of work. According to the manufacturer, sheet moistening in conjunction with handling may be sufficient to prevent the release of copper salts. Continued investigations entailing patient follow-ups, measurements of exposure to dust, etc., are being planned.

\section{REFERENCES:}

1. BARRANCO, V. P. Eczematous dermatitis caused by internal exposure to copper. Arch. dermatol. 106 (1972) 386-387.

2. BAUMSIAG, N., KEEN, P. and PETERING, H. G. Carcinoma of the maxillary antrum and its relationship to trace metal content of smuff. Arch. environ health 23 (1971) $1-5$.

3. FRYKHOLIM, K. O., FRITHIOF, L., FERNSTROM, A. I. B., MOBERGER, G. BLOHIV, S. G. and BJORN, E. Allergy to copper derived from dental alloys as a possible cause of oral lesions of lichen planus. Acta derm. venereol. (Stockh.) 49 (1969) $268-281$.

4. GIAMPICCOLO, P., MINGARY, N., TRIPI, F. and GUYISANO, S. Effetti del rame sulla carie sperimentale del ratto albino. Ann. stomat. (Roma) 17 (1968) $219-224$.

5. GLEASON, M. N., GOSSLIN, R. E., HODGE, H. C. and SMITH, R. P. Clinical toxicology of commercial products. The Williams and Wilkins Co., Baltimore, Md. 1969. $131 \mathrm{p}$.

6. HOLOPAINEN, E. Nasal mucous membrane in atrophic rhinitis with reference 
to symptomfree nasal mucosa. Acta otolaryngol. (Stockh.) (1967): suppl. 227.

7. JAKOBI, H. Ozeana. In: J. BERENDES, R. LINK and F. ZOLLLNER (eds.), Handbuch der Hals-Nasen-Oren-Heilkunde mit einschluss der Grenzgebiete. G. Thieme Verlag, Stutgart 1964, III Bd 443-460.

8. LARSSON, L. G. and MARTENSSON, G. Carcinoma of the paranasal sinuses and the nasal cavities. Acta radiol. (Stocleh.) 42 (1954) $149-153$

9. LUCHSINGER, R. Ärtzwirkungen von $\mathrm{Cu}$ Salzen im Bereich der Nasen-Hals-Organe Z. Unfallverhüt. med. Berufskr. 44 (1951) $274-278$

10. MILES FOXEN, E. $H$. Acute and chronic inflammations of the nose: Nonhealing granuloma. In: $J$, BALLANTYNE and $J$, GROVES (eds.), Scott-Brown's, Diseases of the ear, nose and throat ( 3 d ed.). Butter. worths, London 1972, pp. 123-127.

11. MOESCHLIN, S. Klinik und Therapie der Vergiftungen. G. Thieme Verlag, Stuttgart 1972, p. 147 \& 156

12. MOKHTAR, M., NASR, A. N. and OS-
MAN, M. Nasal atrophy - Aethiopatogenesis. J. egypt. med. assoc. 54 (1971) 417-. 427.

13. MORRIS, G. E. Industrial dermatitis due to contact with brass. New engl. $j$. med. 246 (1952) $366-368$

14. PIMENTEL, $J$ C. and MARQUES, $F$. "Vinyard sprayer's lung": A new occupational disease, Thorax 24 (1969) 678-688

15. SAX, N. I. Dangerous properties of industrial materials. Van Nostrand Reynhold Co, New York, Toronto, London, Mellbourne 1969, pp. 960-961, 1114.

16. STOKINGER, H. E. The metals (excluding lead). In: F. A. PATTY (ed.), Industrial hygiene and toxicology (vol. II). Interscience publishers, New York, Iondon, Sidney 1967, pp. 1035-1036.

17. TRACHTENBERG, D. I. Allergic response to copper - Its possible gingival implica.. tions, $J$, periodontal. 43 (1973) 705-707.

18. WALSCH, F. B. and HOYT, W. F. Clinical neuroophtalmology (3rd ed.). The Williams and Wilkins Co., Baltimore Md. 1969, Bd. 2556 .

Received for publication: 1974-05-03. 